\title{
Local and systemic response to intramammary lipopolysaccharide challenge during long-term manipulated plasma glucose and insulin concentrations in dairy cows
}

\author{
M. C. M. B. Vernay, O. Wellnitz, L. Kreipe, H. A. van Dorland, and R. M. Bruckmaier ${ }^{1}$ \\ Veterinary Physiology, Vetsuisse Faculty University of Bern, Bremgartenstrasse 109a, CH-3001 Bern, Switzerland
}

\begin{abstract}
The metabolic load during periods of high milk production in dairy cows causes a variety of changes of metabolite blood concentrations including dramatically decreased glucose levels. These changes supposedly impair the immune system. The goal of this study was, therefore, to evaluate adaptations of the cow's immune system in response to an intramammary lipopolysaccharide (LPS) stimulation during a 3-d modification of plasma glucose and insulin induced by different clamp infusions. Seventeen midlactating dairy cows received a hypoglycemic hyperinsulinemic clamp induced by insulin infusion (HypoG; $\mathrm{n}=5$ ), a euglycemic hyperinsulinemic clamp induced by insulin and glucose infusion $(\mathrm{EuG} ; \mathrm{n}=6)$, or infusion of saline solution $(\mathrm{NaCl} ; \mathrm{n}$ $=6$ ) for $56 \mathrm{~h}$. At $48 \mathrm{~h}$ of infusion, 2 udder quarters were challenged with $200 \mu \mathrm{g}$ of Escherichia coli LPS. At $48 \mathrm{~h}$ of infusion (immediately before LPS challenge), tumor necrosis factor $\alpha$, lactoferrin, and serum amyloid A (SAA) mRNA abundance was increased in HypoG and Il-1 $\beta$ mRNA abundance was decreased in EuG. After LPS challenge, plasma glucose concentration did not decrease, although plasma insulin increased simultaneously in all groups either due to enhanced endogenous release $(\mathrm{NaCl})$ or due to increased insulin infusion rate (HypoG; EuG). Plasma cortisol, rectal temperatures, and milk somatic cell count of challenged quarters increased, whereas plasma nonesterified fatty acid concentrations were similarly decreased across treatments. In mammary biopsies, increased mRNA expression of tumor necrosis factor $\alpha$, IL-1 $\beta$, IL-8, and IL-10, and SAA were observed in LPS-treated quarters of all groups, with a more pronounced increase in IL-1 $\beta$, IL-10, and SAA expression in EuG. Nuclear factor- $\kappa \mathrm{B}$ mRNA expression was upregulated in $\mathrm{NaCl}$ and $\mathrm{EuG}$ but not in HypoG in response to LPS. Lactoferrin, toll-like receptor 4 , and cyclooxygenase- $2 \mathrm{mRNA}$
\end{abstract}

Received November 24, 2011.

Accepted January 20, 2012.

${ }^{1}$ Corresponding author: rupert.bruckmaier@vetsuisse.unibe.ch expression was increased in LPS-treated quarters of EuG only, and 5-lipoxygenase mRNA expression was decreased in LPS-treated quarters only in treatments HypoG and $\mathrm{NaCl}$. In conclusion, intramammary LPS induces local and systemic inflammatory responses, as well as systemic insulin resistance. The observed treatment differences of the mammary mRNA expression of several immune parameters both before and after LPS challenge indicate a direct influence of changed glucose and insulin concentrations during the course of lactation on the immune defense against mastitis pathogens. Key words: inflammation, insulin resistance, energy homeostasis, mammary immunity

\section{INTRODUCTION}

High milk production levels and simultaneously inadequate nutrient uptake cause a negative energy and nutrient balance in dairy cows (Drackley et al., 2005; Gross et al., 2011a). Negative energy balance (NEB) occurs regularly in dairy cows during the transition period until wk 7 to 9 postpartum (Suriyasathaporn et al., 2000; van Dorland et al., 2009) but can also be induced by insufficient feeding in later lactational stages (Gross et al., 2011a). During periods of NEB, typical endocrine and metabolic adaptations occur (Gross et al., 2011b). In particular, the glucose concentration is low during periods of NEB, frequently accompanied by elevated plasma concentrations of NEFA and ketone bodies (Kessel et al., 2008; Gross et al., 2011a). These metabolic changes usually accompany very low plasma concentrations of insulin, IGF-1, and leptin (Drackley et al., 2005; Gross et al., 2011b).

It is generally assumed that the immune system is impaired during periods of NEB and the vast majority of production diseases, including mastitis, reach the greatest risk level during the transition period (Suriyasathaporn et al., 2000; Ingvartsen, 2006; Pyörälä, 2008). However, because usually an orchestrated metabolic and endocrine adaptation occurs during NEB with several factors changing simultaneously, it could up to now not be shown if changes of the glucose-insulin system are particularly involved in the impairment of the mam- 
mary immune system and consequently responsible for increased susceptibility to mastitis.

Though not identical, many of the intramammary inflammatory aspects of gram-negative IMI can be modeled with the administration of LPS and, to a large extent, perhaps better modeled because of the relatively greater control of dose and intraorgan distribution of the proinflammatory exciter (Hoeben et al., 2000). During an inflammatory response in the mammary gland, the regulation of mRNA expression of numerous factors, such as cytokines, acute phase proteins, and other inflammatory parameters can be observed (reviewed by Wellnitz and Bruckmaier, 2012). Mammary biopsies for this purpose have the advantage that only little tissue $(20-40 \mathrm{mg})$ is needed.

The objective of the present study was to test the hypothesis that plasma glucose and insulin concentrations play a crucial role for the activity of the immune system. Therefore, intramammary and systemic reactions to an intramammary LPS challenge performed were investigated on d 3 of continuously and constantly manipulated concentrations of glucose and insulin through either hyperinsulinemic hypoglycemic or hyperinsulinemic euglycemic clamp, or control $(\mathrm{NaCl})$ experiments.

\section{MATERIALS AND METHODS}

\section{Experimental Animals}

Seventeen healthy lactating, and nonpregnant dairy cows $(7$ Holstein-Friesian, 8 Red Holstein, and 2 Red Holstein $\times$ Simmental), during diestrus in wk 18 to 37 of lactation were used. Animals were in their first to sixth lactation, which was considered for grouping to the experimental treatments. The daily milk yield was $24.6 \pm 1.4 \mathrm{~kg}$ (means $\pm \mathrm{SEM}$ of individual average of $5 \mathrm{~d}$ immediately before the experiment). All udder quarters were free of clinical symptoms of inflammation with an SCC $<150,000 / \mathrm{mL}$.

Two weeks before the start of the experiment, animals were placed in a tie-stall to adapt to the experimental housing and feeding conditions. Animals were fed ad libitum with hay $(5.8 \mathrm{MJ} / \mathrm{kg}$ of $\mathrm{DM})$. In addition, each animal was provided concentrate twice daily based on the individual production level, and once daily $50 \mathrm{~g}$ of minerals. Water was available ad libitum. Milking was performed twice daily at 0530 and $1600 \mathrm{~h}$.

\section{Experimental Design and Treatments}

The experimental procedures followed the Swiss Federal Law on Animal Protection and were approved by the Committee of Animal Experiments of the Canton Fribourg, Switzerland.
Cows were randomly assigned to 1 of the 3 experimental groups, as described in detail by Kreipe et al. (2011). In short, infusions were provided through an indwelling catheter in one jugular vein while blood samples were taken from another catheter inserted in the contralateral jugular vein. Clamp infusions lasted for $56 \mathrm{~h}$ and were started at $0900 \mathrm{~h}$ on $\mathrm{d} 1$. Animals of the group that received a hypoglycemic hyperinsulinemic clamp induced by insulin infusion $($ HypoG; $\mathrm{n}=$ 5 animals) were infused with bovine insulin (\# I4011; Sigma-Aldrich, St. Louis, MO) to decrease blood glucose to a constant level of $2.3 \pm 0.1 \mathrm{mmol} / \mathrm{L}$. The mean insulin infusion rate was $0.6 \pm 0.1 \mathrm{mU} / \mathrm{kg}$ of $\mathrm{BW}$ per minute. Animals of the group that received a euglycemic hyperinsulinemic clamp induced by insulin and glucose infusion (EuG; n $=6$ ) were infused with insulin at a constant infusion rate of $0.6 \mathrm{mU} / \mathrm{kg}$ of $\mathrm{BW}$ per minute (according to the mean infusion rate in group HypoG) and, in addition, with 40\% glucose (Dr. G. Bichsel AG, Interlaken, Switzerland) to maintain pretreatment plasma glucose concentrations $(3.8 \pm 0.2 \mathrm{mmol} / \mathrm{L})$ at simultaneously elevated insulin concentrations. In the control group $(\mathrm{n}=6)$, cows were continuously infused with $0.9 \% \mathrm{NaCl}$ solution at an infusion rate of $20 \mathrm{~mL} / \mathrm{h}$ (Table 1).

An intramammary LPS challenge was performed on d 3 starting at $48 \mathrm{~h}$ of infusion. After disinfection of the teat tip with povidone-iodine [Betadine standardized solution ad us. vet. (for veterinary use); Mundipharma Medical Co., Hamilton/Bermuda, Basel, Switzerland] and $70 \%$ ethanol-soaked compresses, one front and one rear quarter was intramammarily instilled with $200 \mu \mathrm{g}$ of LPS from Escherichia coli serotype O26:B6 (\# L8274; Sigma-Aldrich), diluted in $10 \mathrm{~mL}$ of $\mathrm{NaCl}$ $(0.9 \%)$ solution. The other 2 quarters served as controls and were instilled with $10 \mathrm{~mL}$ of $\mathrm{NaCl}(0.9 \%)$ solution. Abbreviations for all mammary quarters are as follows: LPS challenged and biopsied $\left(\mathbf{L P S}_{\mathrm{B}}\right)$, biopsied only $\left(\mathbf{C}_{\mathrm{B}}\right)$, LPS challenged only $\left(\mathbf{L P S}_{\mathbf{M}}\right)$, and no treatment as control $\left(\mathbf{C}_{\mathbf{M}}\right)$.

\section{Sampling of Cisternal Milk and Rectal Temperature Measurement}

Throughout the experiment, cisternal milk samples $(\sim 20 \mathrm{~mL})$ were collected daily from each quarter after removal of the 3 first milk jets within $50 \mathrm{~s}$ of first touch of the udder (strict foremilk; Bruckmaier and Hilger, 2001) immediately before morning milking. The SCC was determined with a DeLaval cell counter (DeLaval International AB, Tumba, Sweden). The same procedure was used for SCC measurement from the front quarters (1 LPS challenged and 1 control) immediately before and hourly after the LPS challenge until $8 \mathrm{~h}$ af- 
Table 1. Experimental setup

Plasma concentration (mean \pm SEM on d 2)

\begin{tabular}{llll}
$\begin{array}{l}\text { Treatment } \\
\text { group }^{1}\end{array}$ & 56-h infusion & Glucose & Insulin \\
\cline { 2 - 4 } HypoG & Insulin (regulated) & Constant low $(2.3 \pm 0.1 \mathrm{mmol} / \mathrm{L})$ & High $(34.1 \pm 7.7 \mu \mathrm{U} / \mathrm{mL})$ \\
EuG & $\begin{array}{l}\text { Glucose } 40 \%(\text { regulated }) ; \text { insulin } \\
\text { (0.6 mU } / \mathrm{kg} \text { of BW per minute) }\end{array}$ & Constant normal $(3.8 \pm 0.2 \mathrm{mmol} / \mathrm{L})$ & High $(57.4 \pm 9.8 \mu \mathrm{U} / \mathrm{mL})$ \\
$\mathrm{NaCl}$ & $0.9 \% \mathrm{NaCl}(20 \mathrm{~mL} / \mathrm{h})$ & Physiological $(4.2 \pm 0.1 \mathrm{mmol} / \mathrm{L})$ & Physiological $(9.9 \pm 1.8 \mu \mathrm{U} / \mathrm{mL})$ \\
\hline
\end{tabular}

${ }^{1}$ HypoG = cows received a hypoglycemic hyperinsulinemic clamp induced by insulin infusion [infused with bovine insulin (\# I4011; SigmaAldrich, St. Louis, MO) to decrease blood glucose to a constant level of $2.3 \pm 0.1 \mathrm{mmol} / \mathrm{L}$; the mean insulin infusion rate was $0.6 \pm 0.1 \mathrm{mU} /$ $\mathrm{kg}$ of BW per minute]; EuG = cows received a euglycemic hyperinsulinemic clamp induced by insulin and glucose infusion [infused with insulin at a constant infusion rate of $0.6 \mathrm{mU} / \mathrm{kg}$ of BW per minute (according to the mean infusion rate in group HypoG) and, in addition, with $40 \%$ glucose (Dr. G. Bichsel AG, Interlaken, Switzerland) to maintain pretreatment plasma glucose concentrations (3.8 $\pm 0.2 \mathrm{mmol} / \mathrm{L})$ at simultaneously elevated insulin concentrations]; $\mathrm{NaCl}=$ control cows, which were continuously infused with $0.9 \% \mathrm{NaCl}$ solution.

ter challenge (PC). Rectal temperature was measured hourly during the day of LPS challenge. Milking, blood collection, and tissue biopsy were always performed in the same order and completed within 25 min.

\section{Blood Collection}

During the entire 3-d clamp infusions, including the day of LPS challenge, $10-\mathrm{mL}$ blood samples were taken hourly through one jugular vein catheter and added to tubes containing Na-EDTA. Samples were stored on wet ice until centrifugation (at 3,000 $\times g$ for $20 \mathrm{~min}$ at $4^{\circ} \mathrm{C}$ ) for plasma collection and conservation at $-20^{\circ} \mathrm{C}$. Additional blood samples $(1.5 \mathrm{~mL})$ were collected up to every $5 \mathrm{~min}$ for immediate centrifugation and glucose measurement for continuous adjustment of the insulin and glucose infusion rates.

\section{Mammary Gland Biopsies}

Udder tissue biopsies (30-60 mg) of the 2 rear quarters (1 LPS challenged and 1 control) were taken $1 \mathrm{wk}$ before the start of the clamp infusion (d 0). On the day of LPS challenge (d 3), a biopsy was taken immediately before challenge and at $8 \mathrm{~h}$ after challenge as described previously (Schmitz et al., 2004). Before the biopsies, cows were sedated by an intravenous injection of $16 \mu \mathrm{g} / \mathrm{kg}$ of BW of xylazine (Xylazin Streuli ad us. vet.; G. Streuli \& Co. AG, Uznach, Switzerland). The biopsy samples were immediately transferred into $1 \mathrm{~mL}$ of RNA stabilization reagent (RNAlater, Ambion; Applied Biosystems Inc., Austin, TX), and stored at 4C for $24 \mathrm{~h}$ and then frozen at $-80^{\circ} \mathrm{C}$ until extraction of RNA.

\section{Laboratory Analyses}

Plasma glucose and NEFA were measured enzymatically using commercial kits [BioMérieux, Marcy l'Étoile,
France, for glucose (intraassay CV 1.5\%) and Randox Laboratories Ltd., Ibach, Switzerland, for NEFA (intraassay CV 4.8\%), respectively]. Plasma insulin and total cortisol were measured using RIA as described by Vicari et al. (2008) and by Blum et al. (1985), respectively. Inter- and intraassay coefficients of variation for the determination of these hormones were $<15$ and $10 \%$, respectively.

Total RNA was extracted from the biopsies with peqGOLD TriFast (PEQLAB Biotechnologie GmbH, Erlangen, Germany) according to the manufacturer's protocol. Final RNA concentration was measured by spectrophotometry (NanoDrop 2000; Thermo Fischer Scientific Inc., Waltham, MA). One microgram of total RNA was reverse transcribed with Moloney Murine Leukemia Virus Reverse Transcriptase RNase H minus, Point Mutant (MMLV-RT; Promega Corp., Madison, WI) using random hexamer primers (Invitrogen, Leek, the Netherlands). Amplification and quantification of the target cDNA was accomplished by real-time quantitative PCR (qPCR) in a Rotor-Gene 6000 rotary analyzer (Corbett Research, Sydney, Australia) as described previously by Wellnitz et al. (2011). Threshold values (cycle threshold, CT) were achieved by Rotor-Gene software version 1.7.75. The CT values of target genes were normalized to the expression of 3 housekeeping genes (GAPDH, ubiquitin, and cyclophilin B) according to the following equation: $\triangle \mathrm{CT}=\mathrm{CT}$ (arithmetic mean of housekeeping genes) - CT (target gene). To show the infusion-related changes, an average of mRNA expression of both biopsied quarter of each target gene and animal was calculated on d 0 and on d 3 (before LPS challenge). The normalized CT values were set in relation according the equation $\Delta \Delta \mathrm{CT}=\Delta \mathrm{CT}$ [d $3(0$ h)] $-\Delta \mathrm{CT}$ (d 0). Mammary mRNA expression changes induced by LPS stimulation were shown in each biopsied quarter separately according the equation $\Delta \Delta \mathrm{CT}$ $=\Delta \mathrm{CT}[\mathrm{d} 3(8 \mathrm{~h})]-\Delta \mathrm{CT}[\mathrm{d} 3(0 \mathrm{~h})]$. The 3 housekeeping genes were checked for their suitability and finally 
Table 2. Primers of housekeeping and target genes used for the quantitative PCR

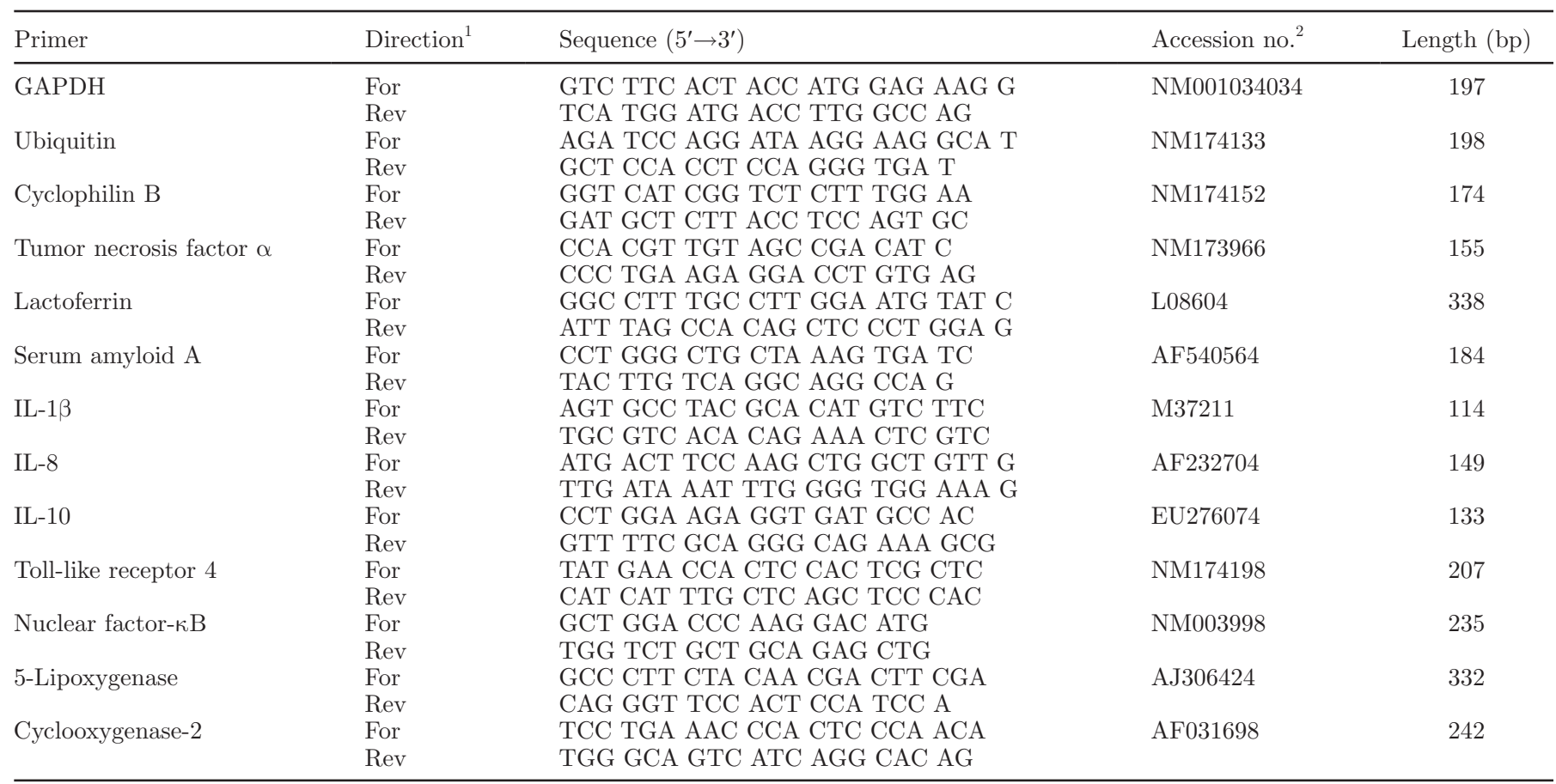

${ }^{1}$ For $=$ forward; Rev $=$ reverse.

${ }^{2}$ Sequences are available in the GenBank database ((http://www.ncbi.nlm.nih.gov/pubmed/) under the given accession numbers as published by Bruckmaier and Hilger (2001), Schmitz et al. (2004), Wellnitz et al. (2006), Griesbeck-Zilch et al. (2008), and Takagi et al. (2008).

used because they showed a constant expression in all samples with nondirected variations within $<1$ cycle. Primers for the housekeeping and target genes were synthesized commercially (Microsynth AG, Balgach, Switzerland) using the sequences shown in Table 2 . As PCR products were sequenced when primers were developed, in this study, only product lengths were respected.

\section{Statistical Evaluations}

Data are presented as means \pm standard errors of the means. Somatic cell counts are presented and statistically evaluated at a logarithmic scale $\left(\log _{10}\right)$ to ensure normal distribution of the data. Differences between treatments within each time point and differences between time points within treatment groups were tested for significance $(P<0.05)$ by ANOVA using a MIXED procedure of SAS (Release 9.2; SAS Institute Inc., Cary, NC). The model included time, group, and their interaction as fixed effects and cow as repeated subject.

\section{RESULTS}

Before LPS administration, constant hypoglycemia was reached in HypoG $(2.3 \pm 0.1 \mathrm{mmol} / \mathrm{L})$, and the concentration of glucose remained constant at the pre- infusion level in $\mathrm{EuG}(3.8 \pm 0.2 \mathrm{mmol} / \mathrm{L})$ and $\mathrm{NaCl}$ $(4.2 \pm 0.1 \mathrm{mmol} / \mathrm{L})$. Also, the insulin infusion rate (IIR) in HypoG and the glucose infusion rate (GIR) in EuG were almost constant during the period before LPS challenge. Further details are described elsewhere (Kreipe et al., 2011).

After LPS challenge, plasma glucose concentration could not be maintained in HypoG cows (i.e., glucose increased at $5 \mathrm{~h} \mathrm{PC}$ although IIR was immediately increased as soon as glucose started to rise). At $6 \mathrm{~h}$, PC glucose decreased again, whereas plasma insulin increased from $4 \mathrm{~h} \mathrm{PC}$ to $6 \mathrm{~h} \mathrm{PC} \mathrm{(Figure} \mathrm{1a).} \mathrm{In} \mathrm{EuG,}$ the GIR had to be continuously decreased from $1 \mathrm{~h} \mathrm{PC}$ until the end of the experiment, whereas plasma insulin and glucose increased similarly from $4 \mathrm{~h} \mathrm{PC} \mathrm{(Figure}$ 1b). Insulin peaked at $6 \mathrm{~h} \mathrm{PC}$ and glucose at $8 \mathrm{~h}$ PC. As shown in Figure 1c, plasma glucose increased at 0 $\mathrm{h} \mathrm{PC}$ and recovered to normal values at $2 \mathrm{~h} \mathrm{PC}$ in the $\mathrm{NaCl}$ group. Plasma insulin started to increase at 4 $\mathrm{h} \mathrm{PC}$ to reach a peak at $6 \mathrm{~h} \mathrm{PC}$. The area under the curve (AUC) of plasma insulin from 0 to $8 \mathrm{~h} \mathrm{PC}$ was not significantly different between groups.

Mean plasma cortisol (Figure 2) increased markedly in all 3 groups within $2 \mathrm{~h}$ PC. In HypoG, the peak was reached at $4 \mathrm{~h} \mathrm{PC}$, in $\mathrm{EuG}$ at $3 \mathrm{~h} \mathrm{PC}$, and in $\mathrm{NaCl}$ at $2 \mathrm{~h}$ PC. After a plateau phase, plasma concentrations decreased in the 3 groups to reach basal values in $\mathrm{Hy}$ - 

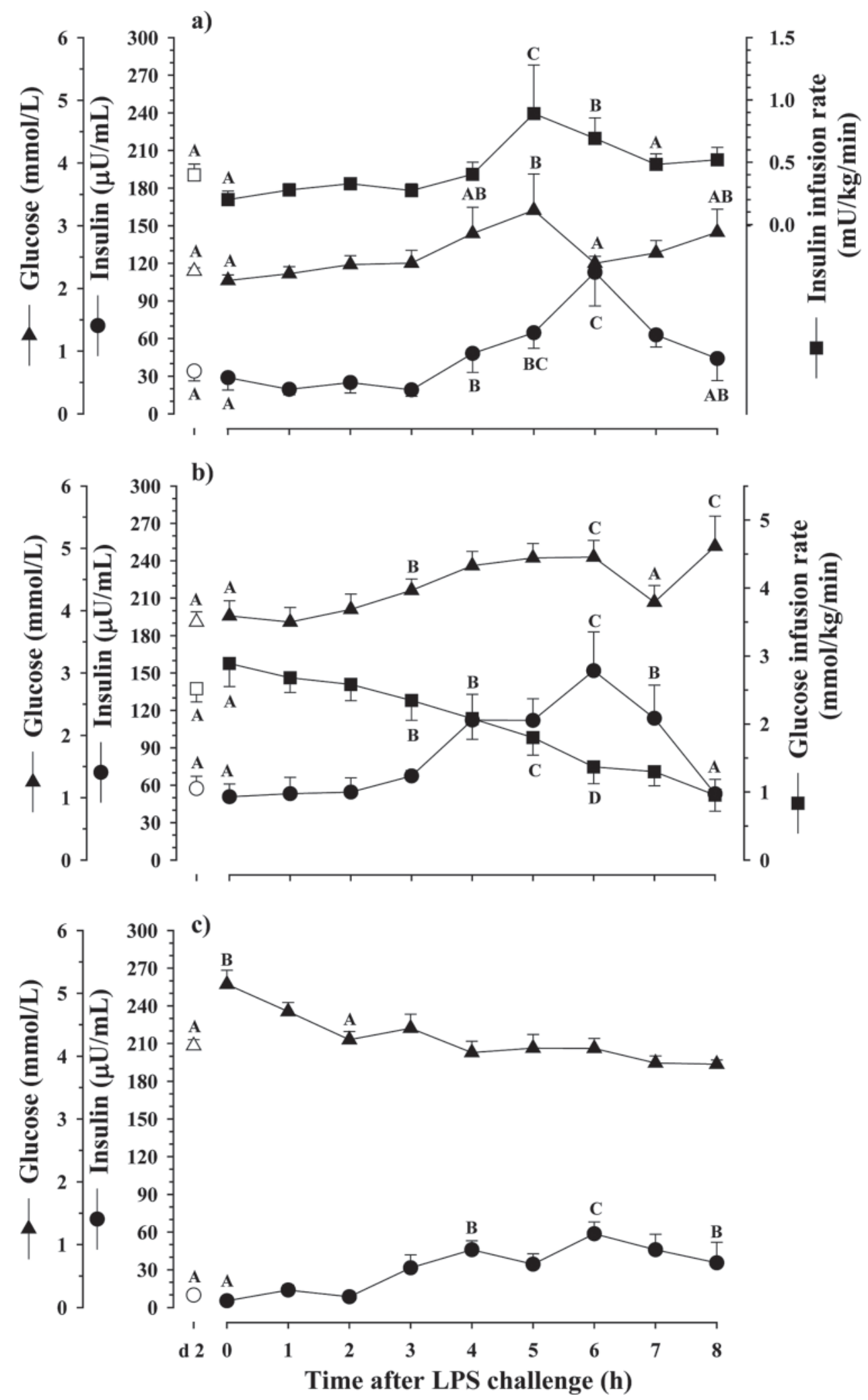

Figure 1. Mean plasma concentrations from 24 to $46 \mathrm{~h}$ of infusion (d 2; open symbols) and hourly evolution of plasma glucose, insulin, and insulin infusion rate in cows that received a hypoglycemic hyperinsulinemic clamp induced by insulin infusion (HypoG; a); of glucose, insulin, and glucose infusion rate in cows that received a euglycemic hyperinsulinemic clamp induced by insulin and glucose infusion (EuG; b); and of glucose and insulin in control cows, which were continuously infused with $0.9 \% \mathrm{NaCl}$ solution $(\mathrm{NaCl}$; c), after LPS challenge. Data are means \pm SEM. Data points without common letters $(\mathrm{A}-\mathrm{D})$ show significant differences $(P<0.05)$ between time points. 


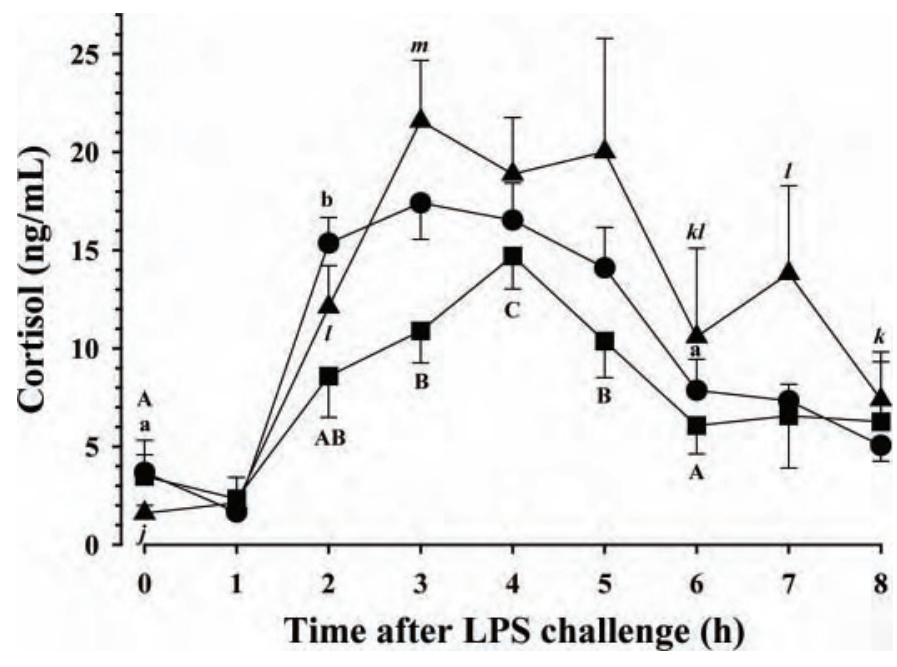

Figure 2. Total plasma cortisol concentrations immediately after LPS challenge. Data are means values \pm SEM for cows that received a hypoglycemic hyperinsulinemic clamp induced by insulin infusion (HypoG; square), cows that received a euglycemic hyperinsulinemic clamp induced by insulin and glucose infusion (EuG; circle), and control cows, which were continuously infused with $0.9 \% \mathrm{NaCl}$ solution $(\mathrm{NaCl}$; triangle). Data points without common letters $(\mathrm{A}-\mathrm{C}$ for HypoG, ${ }^{\mathrm{a}, \mathrm{b}}$ for $\mathrm{EuG}$, and $j-m$ for $\left.\mathrm{NaCl}\right)$ are significantly different $(P$ $<0.05)$.

poG and $\mathrm{EuG}$ at $8 \mathrm{~h} \mathrm{PC}$. In $\mathrm{NaCl}$, the cortisol level at this time was still greater than basal values. The AUC of cortisol from 0 to $8 \mathrm{~h}$ PC did not significantly differ between treatments.

Plasma NEFA concentrations were similar in $\mathrm{NaCl}$ and HypoG on d 2 before the LPS challenge, whereas decreased NEFA concentrations were observed in EuG $(P<0.05)$. In all groups, plasma NEFA concentrations decreased significantly $(P<0.01)$ immediately PC. A plateau was reached within $1 \mathrm{~h}$ in $\mathrm{EuG}$, whereas the decrease continued until $6 \mathrm{~h} \mathrm{PC}$ in HypoG and $\mathrm{NaCl}$ (data not shown).

The SCC of cisternal milk at morning milking of LPS $_{\mathrm{M}}$ and $\mathrm{C}_{\mathrm{M}}$ (quarters without biopsy) did not change in all groups between $\mathrm{d} 0$ and basal values on $\mathrm{d} 3$. The $\mathrm{SCC}$ in $\mathrm{C}_{\mathrm{M}}$ was slightly but significantly increased at 1 $\mathrm{h} P C$ in $\mathrm{EuG}$, and reached almost prechallenge values at $2 \mathrm{~h} \mathrm{PC}$ (Figure 3a). In $\mathrm{NaCl}$ and HypoG, SCC in $\mathrm{C}_{\mathrm{M}}$ remained unchanged after intramammary LPS challenge. The SCC in $\mathrm{LPS}_{\mathrm{M}}$ increased significantly from 3 $\mathrm{h}$ PC $(P<0.01)$ until $8 \mathrm{~h} \mathrm{PC}$ with a peak at $7 \mathrm{~h} \mathrm{PC}$, similarly in all treatments. The AUC of SCC in LPSchallenged quarters from $0 \mathrm{~h}$ to $8 \mathrm{~h} \mathrm{PC}$ did not differ between groups (data not shown).

Rectal temperature increased in all groups from $1 \mathrm{~h}$ $\mathrm{PC}$ to reach values above $40.0^{\circ} \mathrm{C}$ at $4 \mathrm{~h} \mathrm{PC}$ in $\mathrm{EuG}$, and at $5 \mathrm{~h} \mathrm{PC}$ in HypoG and $\mathrm{NaCl}$ (Figure 3b). The AUC from $0 \mathrm{~h}$ to $8 \mathrm{~h}$ PC did not differ between groups (data not shown).
During the treatment period before LPS challenge (d 0 until $48 \mathrm{~h}$ of infusion), the relative mRNA abundance in mammary tissue (individual average of both biopsied quarters) changed only of some of the inflammatory factors. In HypoG, the mRNA abundance of tumor necrosis factor $\alpha(\mathbf{T N F} \boldsymbol{\alpha})$, lactoferrin $(\mathbf{L f})$, and serum amyloid A (SAA) increased $(P<0.05 ; 0.6 \pm 0.3,0.8$ \pm 0.3 , and $1.6 \pm 0.7 \Delta \Delta \mathrm{CT}$, respectively). These parameters did not significantly change in the treatments $\mathrm{EuG}$ and $\mathrm{NaCl}$ before LPS challenge. However, in $\mathrm{EuG}$, the mammary mRNA abundance of IL- $1 \beta$ decreased $(P$ $<0.05 ;-0.8 \pm 0.2 \Delta \Delta \mathrm{CT}$ ), whereas it did not change in the other treatments.

Changes of mammary tissue mRNA abundance in response to intramammary LPS challenge are presented in Table 3. The mRNA abundance of IL-13, IL-8, IL-10, $\mathrm{TNF} \alpha$, and SAA was significantly increased at $8 \mathrm{~h} \mathrm{PC}$ in $\mathrm{LPS}_{\mathrm{B}}(P<0.05)$. Serum amyloid A, IL-8, and IL-10 mRNA abundance was also induced in $\mathrm{C}_{\mathrm{B}}$; however, the increases in $\mathrm{LPS}_{\mathrm{B}}$ were significantly greater than in $\mathrm{C}_{\mathrm{B}}$. Increased mRNA abundance of IL-1 $\beta$, IL-10, and tolllike receptor 4 (TLR-4) in $\mathrm{LPS}_{\mathrm{B}}$ was more pronounced in EuG than in both other groups, and SAA increased more in EuG than in HypoG and $\mathrm{NaCl}(P<0.05)$. The mRNA abundance of nuclear factor- $\kappa \mathrm{B}$ (NF$\boldsymbol{\kappa} \mathbf{B})$ was unchanged in HypoG, whereas an increase was observed in both other groups. In $\mathrm{C}_{\mathrm{B}}$, the mRNA abundance of IL-1 $\beta$, IL-10, and TLR-4 8 h PC was significantly greater in EuG than in HypoG, whereas SAA was decreased in HypoG compared with other groups. No change was seen in the mRNA abundance of Lf without differences between quarters, except in EuG, where it was upregulated in $\mathrm{LPS}_{\mathrm{B}}$. 5-Lipoxygenase mRNA remained unchanged in $\mathrm{LPS}_{\mathrm{B}}$ in EuG and similarly decreased in all other quarters. Mammary mRNA of cyclooxygenase- 2 was increased in $\mathrm{LPS}_{\mathrm{B}}$ in $\mathrm{EuG}$ and unchanged in all quarters of both other groups.

\section{DISCUSSION}

The results of the present study indicate that LPS challenge resulted in both local intramammary and systemic effects. The systemic effects were obvious in all treatment groups by an increase of rectal temperature and plasma cortisol similar to increases found in previous studies (Hoeben et al., 2000; Lehtolainen et al., 2003; Waldron et al., 2006), and by the dramatic influence on the glucose-insulin system. The elevation of glucose concentrations, despite increased IIR in group HypoG, and despite downregulated GIR in group EuG at simultaneously elevated insulin plasma concentrations in all treatments, clearly indicates the development of a systemic insulin resistance in response to LPS challenge, possibly with a concomitant increase of 

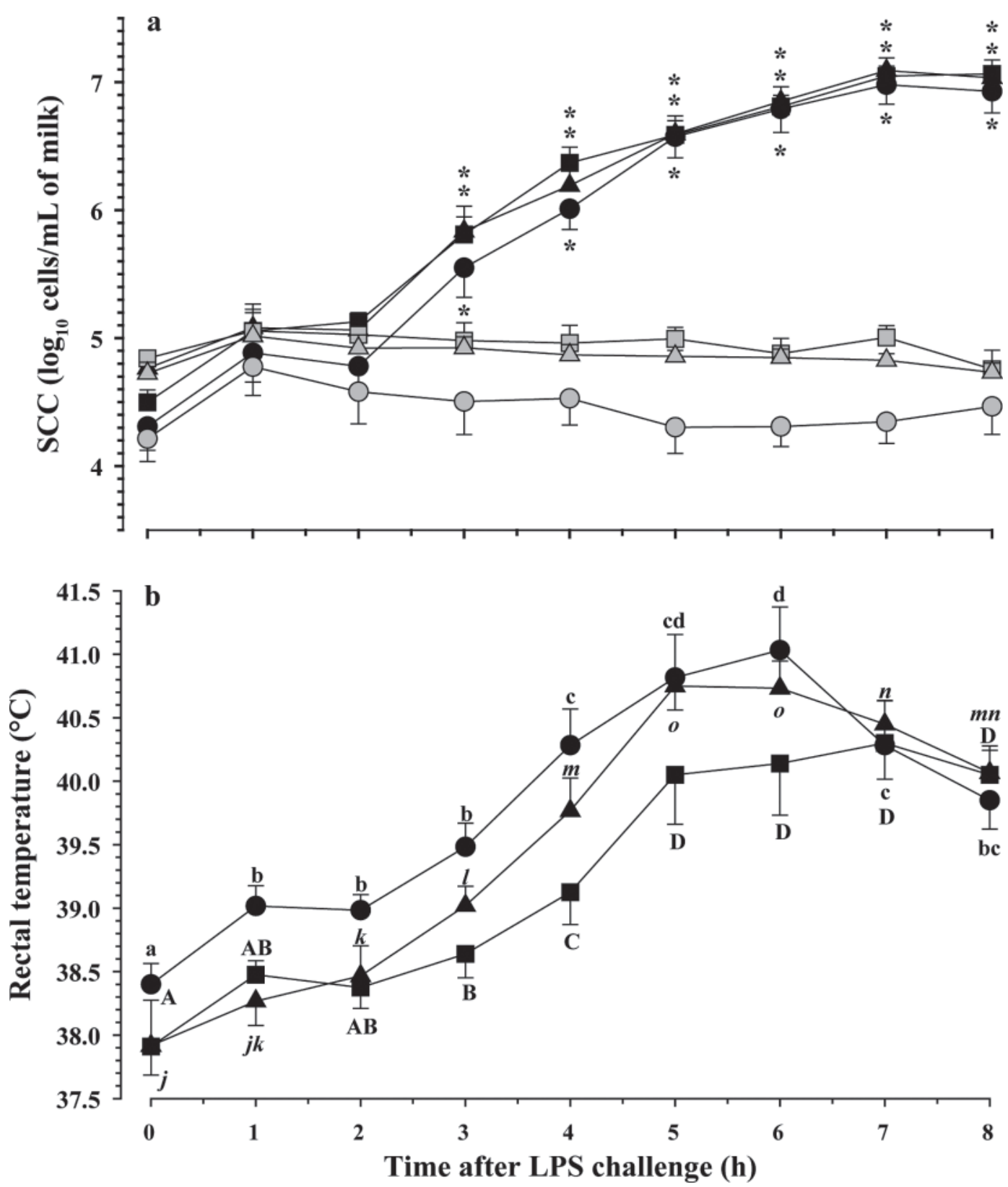

Figure 3. Somatic cell count (in $\log _{10}$ scale) in cisternal milk (a), and rectal temperature (b) after the LPS challenge. Data are means \pm SEM for cows that received a hypoglycemic hyperinsulinemic clamp induced by insulin infusion (HypoG; square), cows that received a euglycemic hyperinsulinemic clamp induced by insulin and glucose infusion (EuG; circle), and control cows, which were continuously infused with $0.9 \%$ NaCl solution ( $\mathrm{NaCl}$; triangle). In (a), measurements from the LPS-stimulated quarters $\left(\mathrm{LPS}_{\mathrm{M}}\right)$ are shown in black, and from the control quarters $\left(\mathrm{C}_{\mathrm{M}}\right)$ in gray. Highly significant $(P<0.01)$ increases from baseline values are indicated with $(*)$. In $(\mathrm{b})$, data points without common letters $(\mathrm{A}-\mathrm{D}$ for HypoG, a-d for $\mathrm{EuG}$, and $j-o$ for $\mathrm{NaCl})$ are significantly different $(P<0.05)$.

hepatic glycogenolysis and gluconeogenesis induced by the increased release of adrenal cortisol. Interestingly, the increase of plasma glucose occurs later in HypoG than in EuG, indicating that due to the 2-d hypoglycemia, glycogen cannot be mobilized in HypoG, and the increase of plasma glucose is mainly derived from gluconeogenesis. The physiological role of this reaction may be to make a maximum of glucose available for the immune reaction. A link between inflammation and insulin insensitivity was repeatedly described in human and animal studies (reviewed by Grimble, 2002). An insulin resistance was previously suggested during sepsis in rats (Lang, 1992) and during systemic LPS infusion in steers (McMahon et al., 1998). Some authors 
Table 3. Changes in mammary mRNA abundance $8 \mathrm{~h}$ after challenge from baseline values on $\mathrm{d} 3^{1}$

\begin{tabular}{|c|c|c|}
\hline Group $^{2}$ & $\mathrm{C}_{\mathrm{B}}$ & $\mathrm{LPS}_{\mathrm{B}}$ \\
\hline \multicolumn{3}{|l|}{ IL-1 $\beta$} \\
\hline $\mathrm{NaCl}$ & $0.8 \pm 0.6^{\mathrm{ab}}$ & $2.9 \pm 0.6^{\mathrm{A} * \dagger}$ \\
\hline EuG & $2.2 \pm 0.4^{\mathrm{b} *}$ & $5.3 \pm 1.0^{\mathrm{B} * \dagger}$ \\
\hline HypoG & $0.4 \pm 0.3^{\mathrm{a}}$ & $3.4 \pm 0.5^{\mathrm{A} * \dagger}$ \\
\hline \multicolumn{3}{|l|}{ IL-8 } \\
\hline $\mathrm{NaCl}$ & $3.7 \pm 0.6^{*}$ & $7.0 \pm 0.9^{* \dagger}$ \\
\hline $\mathrm{EuG}$ & $5.0 \pm 0.5^{*}$ & $8.5 \pm 0.7^{* \dagger}$ \\
\hline HypoG & $3.1 \pm 0.6^{*}$ & $7.5 \pm 0.7^{* \dagger}$ \\
\hline \multicolumn{3}{|l|}{ IL-10 } \\
\hline $\mathrm{NaCl}$ & $1.6 \pm 0.5^{\mathrm{ab} *}$ & $2.7 \pm 0.4^{\mathrm{A} *}$ \\
\hline $\mathrm{EuG}$ & $2.6 \pm 0.5^{\mathrm{b} *}$ & $4.9 \pm 0.8^{\mathrm{B} * \dagger}$ \\
\hline HypoG & $0.5 \pm 0.6^{\mathrm{a}}$ & $2.4 \pm 0.6^{\mathrm{A} * \dagger}$ \\
\hline \multicolumn{3}{|c|}{ Tumor necrosis factor $\alpha$} \\
\hline $\mathrm{NaCl}$ & $0.7 \pm 0.4$ & $2.7 \pm 0.8^{* \dagger}$ \\
\hline $\mathrm{EuG}$ & $1.0 \pm 0.3$ & $3.4 \pm 0.7^{* \dagger}$ \\
\hline HypoG & $0.1 \pm 0.6$ & $2.7 \pm 1.0^{*^{\dagger}}$ \\
\hline \multicolumn{3}{|c|}{ Serum amyloid A } \\
\hline $\mathrm{NaCl}$ & $2.7 \pm 1.0^{\mathrm{a} *}$ & $6.0 \pm 1.0^{\mathrm{AB} * \dagger}$ \\
\hline $\mathrm{EuG}$ & $2.1 \pm 0.5^{\mathrm{a} *}$ & $7.9 \pm 0.5^{\mathrm{B} * \dagger}$ \\
\hline HypoG & $-1.3 \pm 1.0^{\mathrm{b}}$ & $4.4 \pm 1.3^{\mathrm{A} * \dagger}$ \\
\hline \multicolumn{3}{|c|}{ Toll-like receptor 4} \\
\hline $\mathrm{NaCl}$ & $-0.9 \pm 0.3^{\mathrm{ab} *}$ & $-0.8 \pm 0.7^{\mathrm{A}}$ \\
\hline $\mathrm{EuG}$ & $0.1 \pm 0.2^{\mathrm{a}}$ & $1.0 \pm 0.4^{\mathrm{B} *}$ \\
\hline HypoG & $-1.4 \pm 0.3^{\mathrm{b} *}$ & $-0.9 \pm 0.2^{\mathrm{A}}$ \\
\hline \multicolumn{3}{|c|}{ Nuclear factor- $\kappa B$} \\
\hline $\mathrm{NaCl}$ & $-0.2 \pm 0.7$ & $3.2 \pm 0.5^{\mathrm{B} * \dagger}$ \\
\hline $\mathrm{EuG}$ & $-0.0 \pm 0.5$ & $2.3 \pm 0.5^{\mathrm{B} * \dagger}$ \\
\hline HypoG & $1.2 \pm 0.2$ & $0.5 \pm 0.6^{\mathrm{A}}$ \\
\hline \multicolumn{3}{|c|}{ Lactoferrin } \\
\hline $\mathrm{NaCl}$ & $0.9 \pm 0.4^{\mathrm{a}}$ & $1.0 \pm 0.7^{\mathrm{AB}}$ \\
\hline $\mathrm{EuG}$ & $0.2 \pm 0.4^{\mathrm{a}}$ & $1.8 \pm 0.4^{\mathrm{B} * \dagger}$ \\
\hline HypoG & $-0.9 \pm 0.5^{\mathrm{b}}$ & $0.1 \pm 0.6^{\mathrm{A}}$ \\
\hline \multicolumn{3}{|c|}{ 5-Lipoxygenase } \\
\hline $\mathrm{NaCl}$ & $-1.2 \pm 0.3^{*}$ & $-2.5 \pm 0.5^{\mathrm{B} *}$ \\
\hline $\mathrm{EuG}$ & $-1.3 \pm 0.4^{*}$ & $-1.0 \pm 0.7^{\mathrm{A}}$ \\
\hline HypoG & $-1.3 \pm 0.4^{*}$ & $-2.3 \pm 0.4^{\mathrm{AB} *}$ \\
\hline \multicolumn{3}{|c|}{ Cyclooxygenase-2 } \\
\hline $\mathrm{NaCl}$ & $-1.5 \pm 0.3^{\mathrm{b} *}$ & $-0.2 \pm 0.4^{\mathrm{A} \dagger}$ \\
\hline $\mathrm{EuG}$ & $-0.1 \pm 0.3^{\mathrm{a}}$ & $1.6 \pm 0.5^{\mathrm{B} * \dagger}$ \\
\hline HypoG & $-1.5 \pm 0.4^{\mathrm{b} *}$ & $-0.2 \pm 0.3^{\mathrm{A} \dagger}$ \\
\hline
\end{tabular}

${ }_{\mathrm{a}, \mathrm{b}}$ For the control quarter (biopsied only; $\mathrm{C}_{\mathrm{B}}$ ), means with different superscript letters within the column differ between groups $(P<0.05)$.

${ }^{\mathrm{A}, \mathrm{B}}$ For the LPS-challenged and biopsied quarter $\left(\mathrm{LPS}_{\mathrm{B}}\right)$, means with different superscript letters within the column differ between groups $(P<0.05)$

${ }^{1}$ Data are presented as means \pm SEM.

${ }^{2} \mathrm{HypoG}=$ hypoglycemic hyperinsulinemic clamp group; $\mathrm{EuG}=\mathrm{eu}-$ glycemic hyperinsulinemic clamp group; $\mathrm{NaCl}=$ physiological saline solution group (control).

* Means were different from baseline values on d $3(P<0.05)$.

$\dagger$ Means higher in $\mathrm{LPS}_{\mathrm{B}}$ than in $\mathrm{C}_{\mathrm{B}}(P<0.05)$.

suggest that decreased peripheral glucose utilization by inflammation is most likely a pathophysiological phenomenon to provide energy precursors for the immune system (Mészáros et al., 1988; Grimble, 2002). In agreement with our findings, constant plasma glucose at simultaneously increased plasma insulin concentrations was shown after an intramammary LPS challenge in early lactating dairy cows (Waldron et al., 2006).
Those authors interpreted the effect as a consequence of increased hepatic gluconeogenesis, and simultaneously decreased mammary glucose utilization after LPS challenge.

The dramatic but transient elevation of cortisol plasma concentration after LPS challenge in all treatments is consistent with previous studies after natural or LPS-induced coliform mastitis (Lehtolainen et al., 2003; Waldron et al., 2003; Huszenicza et al., 2004). It is known that emotional or physical stressors, proinflammatory cytokines (e.g., TNF $\alpha$, IL-1 $\beta$, and IL-6), and other humoral mediators of inflammation induce the production and release of glucocorticoids from the adrenal cortex through activation of the hypothalamicpituitary-adrenal axis (Christison and Johnson, 1972; Tsigos and Chrousos, 2002). High concentration of plasma cortisol has also been associated with insulin resistance in different mammalian species, in particular during Cushing syndrome (Rizza et al., 1982; Andrews and Walker, 1999).

Decreased concentrations of plasma NEFA after LPS challenge have been previously reported (Waldron et al., 2006) and are likely related to lipogenic and antilipolytic, effects of LPS and proinflammatory cytokines (Waldron et al., 2006).

In all 3 groups, the SCC in $\mathrm{C}_{\mathrm{M}}$ and $\mathrm{LPS}_{\mathrm{M}}$ did not change during the clamp infusion before LPS administration, and showed a similar dramatic increase in response to LPS challenge in all groups (Schmitz et al., 2004; Wellnitz et al., 2011) suggesting no effects of the experimentally induced changes in plasma glucose and insulin and other blood plasma traits (in detail shown by Kreipe et al., 2011).

The expression of mRNA of several factors was measured in mammary tissue biopsies, which contain mostly mammary epithelial cells. Measurements focused on factors that are of specific relevance of the mammary immune system and that are known to be regulated during the mammary immune response. Increases in mammary mRNA abundance of TNF $\alpha$, Lf, and SAA at $48 \mathrm{~h}$ of infusion were obvious only in HypoG and suggest an influence of low plasma glucose (and possibly high insulin) on these factors. On the contrary, IL-1 $\beta$ was downregulated at $48 \mathrm{~h}$ of infusion in the EuG group showing a negative effect of hyperinsulinemic euglycemia on this parameter.

Mammary mRNA abundance of proinflammatory cytokines TNF $\alpha$ and IL- $1 \beta$ were increased in the LPSstimulated quarters at $8 \mathrm{~h} \mathrm{PC}$, whereas they did not change in the control quarters, consistent with previous studies (Schmitz et al., 2004; De Schepper et al., 2008). Similar observations in the 3 treatment groups for TNF $\alpha$ and IL-1 $\beta$ suggest that this effect is not in- 
fluenced by modified plasma insulin or glucose, or both. The increase of IL-1 $\beta$ mRNA abundance was more pronounced in EuG than in other groups. However, based on the prechallenge decrease of mRNA abundance of IL-1 $\beta$ in EuG, the PC elevation started at a decreased baseline level. Obviously, the regulation of IL-1 $\beta$ before and after LPS challenge is influenced by the abundant presence of glucose and concomitant high insulin. The mammary mRNA abundance of the cytokines IL-8, IL10 , and the acute phase protein SAA was increased in both $\mathrm{LPS}_{\mathrm{B}}$ and $\mathrm{C}_{\mathrm{B}}$ quarters at $8 \mathrm{~h} \mathrm{PC}$; however, the change was more pronounced in $\mathrm{LPS}_{\mathrm{B}}$ than in $\mathrm{C}_{\mathrm{B}}$ in all treatment groups. This demonstrates the stimulating effect of both LPS and a traumatic insult on the release of these factors (Hoch et al., 1993; Schmitz et al., 2004) without an influence of plasma insulin-glucose status. Although these observations are similar in all groups, IL-8 mRNA abundance seems to be accentuated in EuG for IL-10 or SAA. This effect could be attributed to the proinflammatory role of glucose described by Dandona et al. (2009). The increased mRNA abundance of LPS-specific receptor TLR4, bacteriostatic protein lactoferrin, and the key enzyme for prostaglandin formation, cyclooxygenase-2, in LPS-challenged quarters was shown in previous studies (Schmitz et al., 2004; Petzl et al., 2008). However, in the present study, an increased mRNA abundance of these factors was only observed in the EuG group. It is possible that the duration of the challenge $(8 \mathrm{~h})$ in this study was not sufficient to observe an increase in mRNA abundance and only in the EuG group did the proinflammatory effects of glucose increase the transcription of these factors (Dandona et al., 2009). The decreased or unchanged mRNA abundance of 5-lipoxygenase (key enzyme in leukotriene synthesis) in mammary tissue in all treatments is consistent with previous observations (Schmitz et al., 2004) and this was potentially not influenced by glucose and insulin plasma concentrations.

The mRNA abundance of NF- $\kappa \mathrm{B}$ increased in the LPS-stimulated quarters in $\mathrm{EuG}$ and $\mathrm{NaCl}$ treatment but remained unchanged in LPS-treated quarters in the HypoG group. Likely, hypoglycemia inhibits the stimulation of NF- $\mathrm{KB}$ as an important constituent of the stimulatory pathway of the innate immune system. Dandona et al. (2009) noted an activation of NF-kB by high glucose in immune cells in human and rodent models. This finding can explain the upregulation of the inflammatory parameters IL-1 $\beta$, IL-8, or IL-10 in $\mathrm{EuG}$ in our study. In addition, the lack of NF- $\kappa \mathrm{B}$ mRNA upregulation in response to LPS in the HypoG group could explain the impaired immune reaction during early lactation when glucose plasma concentration is usually very low (Ingvartsen, 2006; Pyörälä, 2008).

\section{CONCLUSIONS}

The induction of local and systemic inflammatory responses by intramammary LPS challenge is influenced by the metabolic status in dairy cows. The obvious induction of an insulin resistance and possibly also glycogenolysis and gluconeogenesis in response to LPS challenge represents a reaction to maximize glucose concentration in plasma to be available for the immune system. Treatment effects on the mammary mRNA expression of immune parameters both before and after LPS challenge are obvious. These treatment effects on the regulation of immune parameters suggest a direct effect of changed glucose and insulin concentrations during lactation of dairy cows on the mammary immune defense.

\section{ACKNOWLEDGMENTS}

We thank our colleagues at Vetsuisse Faculty, University of Bern, Switzerland: Alexa Oppliger for her important contribution, Claudine Morel, Chantal Philipona, and Yolande Zbinden for the technical assistance, and Mohammed Y. S. A. Mosa for the precious help during animal experiments and laboratory work. This study was supported by the Swiss National Science Foundation (Bern, Switzerland; project no. 120317).

\section{REFERENCES}

Andrews, R. C., and B. R. Walker. 1999. Glucocorticoids and insulin resistance: Old hormones, new targets. Clin. Sci. 96:513-523.

Blum, J. W., F. Jans, W. Moses, D. Fröhli, M. Zemp, M. Wanner, I. C. Hart, R. Thun, and U. Keller. 1985. Twenty-four-hour pattern of blood hormone and metabolite concentrations in high-yielding dairy cows: Effects of feeding low or high amounts of starch, or crystalline fat. Zentralbl. Veterinarmed. A 32:401-418.

Bruckmaier, R. M., and M. Hilger. 2001. Milk ejection in dairy cows at different degrees of udder filling. J. Dairy Res. 68:369-376.

Christison, G. I., and H. D. Johnson. 1972. Cortisol turnover in heatstressed cows. J. Anim. Sci. 35:1005-1010.

Dandona, P., A. Chaudhuri, H. Ghanim, and P. Mohanty. 2009. Insulin as an anti-inflammatory and antiatherogenic modulator. J. Am. Coll. Cardiol. 53(Suppl.):S14-S20.

De Schepper, S., A. De Ketelaere, D. D. Bannerman, M. J. Paape, L. Peelman, and C. Burvenich. 2008. The toll-like receptor-4 (TLR4) pathway and its possible role in the pathogenesis of Escherichia coli mastitis in dairy cattle. Vet. Res. 39:5.

Drackley, J. K., H. M. Dann, G. N. Douglas, N. A. Janovick Guretzky, N. B. Litherland, J. P. Underwood, and J. J. Loor. 2005. Physiological and pathological adaptations in dairy cows that may increase susceptibility to periparturient diseases and disorders. Ital. J. Anim. Sci. 4:323-344.

Griesbeck-Zilch, B., H. H. D. Meyer, C. Kühn, M. Schwerin, and O. Wellnitz. 2008. Staphylococcus aureus and Escherichia coli cause deviating expression profiles of cytokines and lactoferrin messenger ribonucleic acid in mammary epithelial cells. J. Dairy Sci. 91:2215-2224.

Grimble, R. F. 2002. Inflammatory status and insulin resistance. Curr. Opin. Clin. Nutr. Metab. Care 5:551-559. 
Gross, J., H. A. van Dorland, R. M. Bruckmaier, and F. J. Schwarz. 2011a. Performance and metabolic profile of dairy cows during a lactational and deliberately induced negative energy balance with subsequent realimentation. J. Dairy Sci. 94:1820-1830.

Gross, J., H. A. van Dorland, F. J. Schwarz, and R. M. Bruckmaier. 2011b. Endocrine changes and liver mRNA abundance of somatotropic axis and insulin system constituents during negative energy balance at different stages of lactation in dairy cows. J. Dairy Sci. 94:3484-3494.

Hoch, R. C., R. Rodriguez, T. Manning, M. Bishop, P. Mead, W. C. Shoemaker, and E. Abraham. 1993. Effects of accidental trauma on cytokine and endotoxin production. Crit. Care Med. 21:839-845.

Hoeben, D., C. Burvenich, E. Trevisi, G. Bertoni, J. Hamann, R. M. Bruckmaier, and J. W. Blum. 2000. Role of endotoxin and TNF- $\alpha$ in the pathogenesis of experimentally induced coliform mastitis in periparturient cows. J. Dairy Res. 67:503-514.

Huszenicza, G., S. Jánosi, A. Gáspárdy, and M. Kulcsár. 2004. Endocrine aspects in pathogenesis of mastitis in postpartum dairy cows. Anim. Reprod. Sci. 82-83:389-400.

Ingvartsen, K. L. 2006. Feeding- and management-related diseases in the transition cow: Physiological adaptations around calving and strategies to reduce feeding-related diseases. Anim. Feed Sci. Technol. 126:175-213.

Kessel, S., M. Stroehl, H. H. D. Meyer, S. Hiss, H. Sauerwein, F. J. Schwarz, and R. M. Bruckmaier. 2008. Individual variability in physiological adaptation to metabolic stress during early lactation in dairy cows kept under equal conditions. J. Anim. Sci. 86:2903-2912.

Kreipe, L., M. C. M. B. Vernay, A. Oppliger, O. Wellnitz, R. M. Bruckmaier, and H. A. van Dorland. 2011. Induced hypoglycemia for 48 hours indicates differential glucose and insulin effects on liver metabolism in dairy cows. J. Dairy Sci. 94:5435-5448.

Lang, C. H. 1992. Sepsis-induced insulin resistance in rats is mediated by a beta-adrenergic mechanism. Am. J. Physiol. 263:E703-E711.

Lehtolainen, T., S. Suominen, T. Kutila, and S. Pyörälä. 2003. Effect of intramammary Escherichia coli endotoxin in early- vs. latelactating dairy cows. J. Dairy Sci. 86:2327-2333.

McMahon, C. D., T. H. Elsasser, D. R. Gunter, L. G. Sanders, B. P. Steele, and J. L. Sartin. 1998. Estradiol/progesterone implants increase food intake, reduce hyperglycemia and increase insulin resistance in endotoxic steers. J. Endocrinol. 159:469-478.

Mészáros, K., C. H. Lang, G. J. Bagby, and J. J. Spitzer. 1988. In vivo glucose utilization by individual tissues during nonlethal hypermetabolic sepsis. FASEB J. 2:3083-3086.

Petzl, W., H. Zerbe, J. Günther, W. Yang, H.-M. Seyfert, G. Nürnberg, and H.-J. Schuberth. 2008. Escherichia coli, but not Staphylococcus aureus triggers an early increased expression of factors contributing to the innate immune defense in the udder of the cow. Vet. Res. 39:18.
Pyörälä, S. 2008. Mastitis in post-partum dairy cows. Reprod. Domest. Anim. 43(Suppl. 2):252-259.

Rizza, R. A., L. J. Mandarino, and J. E. Gerich. 1982. Cortisol-induced insulin resistance in man: Impaired suppression of glucose production and stimulation of glucose utilization due to a postreceptor defect of insulin action. J. Clin. Endocrinol. Metab. 54:131-138.

Schmitz, S., M. W. Pfaffl, H. H. D. Meyer, and R. M. Bruckmaier. 2004. Short-term changes of mRNA expression of various inflammatory factors and milk proteins in mammary tissue during LPSinduced mastitis. Domest. Anim. Endocrinol. 26:111-126.

Suriyasathaporn, W., C. Heuer, E. N. Noordhuizen-Stassen, and Y. H. Schukken. 2000. Hyperketonemia and the impairment of udder defense: A review. Vet. Res. 31:397-412.

Takagi, M., D. Yamamoto, S. Ogawa, T. Otoi, M. Ohtani, and A. Miyamoto. 2008. Messenger RNA expression of angiotensin-converting enzyme, endothelin, cyclooxygenase- 2 and prostaglandin synthases in bovine placentomes during gestation and the postpartum period. Vet. J. 177:398-404.

Tsigos, C., and G. P. Chrousos. 2002. Hypothalamic-pituitary-adrenal axis, neuroendocrine factors and stress. J. Psychosom. Res. 53:865-871.

van Dorland, H. A., S. Richter, I. Morel, M. G. Doherr, N. Castro, and R. M. Bruckmaier. 2009. Variation in hepatic regulation of metabolism during the dry period and in early lactation in dairy cows. J. Dairy Sci. 92:1924-1940.

Vicari, T., J. J. G. C. van den Borne, W. J. J. Gerrits, Y. Zbinden, and J. W. Blum. 2008. Postprandial blood hormone and metabolite concentrations influenced by feeding frequency and feeding level in veal calves. Domest. Anim. Endocrinol. 34:74-88.

Waldron, M. R., A. E. Kulick, A. W. Bell, and T. R. Overton. 2006. Acute experimental mastitis is not causal toward the development of energy-related metabolic disorders in early postpartum dairy cows. J. Dairy Sci. 89:596-610.

Waldron, M. R., T. Nishida, B. J. Nonnecke, and T. R. Overton. 2003. Effect of lipopolysaccharide on indices of peripheral and hepatic metabolism in lactating cows. J. Dairy Sci. 86:3447-3459.

Wellnitz, O., E. T. Arnold, and R. M. Bruckmaier. 2011. Lipopolysaccharide and lipoteichoic acid induce different immune responses in the bovine mammary gland. J. Dairy Sci. 94:5405-5412.

Wellnitz, O., and R. M. Bruckmaier. 2012. The innate immune response of the bovine mammary gland to bacterial infection. Vet. J. In press. http://dx.doi.org/10.1016/j.tvj1.2011.09.013.

Wellnitz, O., P. Reith, and H. H. D. Meyer. 2006. Immune relevant gene expression of mammary epithelial cells and their influence on leukocyte chemotaxis in response to different mastitis pathogens. Vet. Med. Czech 51:125-132. 